\title{
Construction and immune efficacy of recombinant pseudorabies virus expressing PrM-E proteins of Japanese encephalitis virus genotype I
}

\author{
Ping Qian ${ }^{1,2,3}$, Xianwei Zhi ${ }^{1,2}$, Bo Wang ${ }^{1,2}$, Huawei Zhang ${ }^{1,2}$, Huanchun Chen ${ }^{1,2,3}$ and Xiangmin Li $^{1,2,3^{*}}$
}

\begin{abstract}
Background: Japanese encephalitis (JE) is an arboviral disease with high case fatality rates and neurologic or psychiatric sequelae among survivors in Asia, western Pacific countries and northern Australia. Japanese encephalitis virus (JEV) is the cause of JE and the emergence of genotype I (GI) JEV has displaced genotype III (GIII) as the dominant strains circulating in some Asian regions. The currently available JE vaccines are safe and effective in preventing this disease, but they are developed based on the GIII JEV strains.

Methods: The recombinant virus PRV TK ${ }^{-} / \mathrm{gE}^{-} / \mathrm{PrM} \mathrm{E}^{+}$which expressed the premembrane (prM) and envelope (E) proteins of JEV SX09S-01 strain (genotype I, GI) was constructed by homologous recombination between the genome of PRV TK $/ \mathrm{gE}^{-} / \mathrm{LacZ}^{+}$digested with EcoRI and plasmid plE-CAG-PrM-E-BGH. Expression of JEV PrM and E proteins was analyzed by Western blot analysis. Immune efficacy of PRV TK- $/ g E^{-} / P r M-E^{+}$was further evaluated in mouse model.

Results: A recombinant pseudorabies virus (PRV TK $/ \mathrm{gE}^{-} / \mathrm{PrM}^{-} \mathrm{E}^{+}$) was successfully constructed. Mice experiments showed that PRV TK $\mathrm{TK}^{-} / \mathrm{gE} / \mathrm{PrM}-\mathrm{E}^{+}$could induce a high level of ELISA antibodies against PRV and JEV, as well as high titer of PRV neutralizing antibodies. After challenge with $1 \times 10^{7}$ PFU virulent JEV SX09S-01 strain, the time of death was delayed and the survival rate was improved in PRV TK- $/ \mathrm{gE}^{-} / \mathrm{PrM}^{-\mathrm{E}^{+}}$vaccinated mice.
\end{abstract}

Conclusions: PRV TK- $/ \mathrm{gE}^{-} / \mathrm{PrM}-\mathrm{E}^{+}$is a potential vaccine candidate against PRV and JEV GI infection in the future.

Keywords: Japanese encephalitis virus, Pseudorabies virus, Recombinant virus, PrM-E, Genotype I, Immune efficacy

\section{Background}

Japanese encephalitis (JE) is a zoonotic disease and cause viral encephalitis with serious public health problem in Asia, western Pacific countries and northern Australia [1]. Japanese encephalitis virus (JEV), the etiological agent of $\mathrm{JE}$, is the leading cause of epidemic encephalitis afflicting humans with 68,000 cases annually and $10-50 \%$ fatality. $30-50 \%$ of survivors result in permanent neuropsychiatric sequelae [2-6]. JEV is also an important pathogen in swine. It causes reproductive disorders with abortion and

\footnotetext{
* Correspondence: lixiangmin@mail.hzau.edu.cn

'State Key Laboratory of Agricultural Microbiology, Huazhong Agricultural University, Wuhan, Hubei, P.R. China

'Laboratory of Animal Virology, College of Veterinary Medicine, Huazhong Agricultural University, Wuhan, Hubei, P.R. China

Full list of author information is available at the end of the article
}

weak piglets [7]. Pigs and birds are the major amplifying hosts of JEV from which infected mosquitoes transmit the virus to humans [8].

JEV is an arbovirus with a single strand positive sense RNA belonging to the flaviviridae family and genus flavivirus $[2,3]$. The JEV genome is about $11 \mathrm{~kb}$ in length with $5^{\prime}$ and $3^{\prime}$ non-translated regions (NTRs), coding three structural proteins $(\mathrm{C}, \mathrm{prM} / \mathrm{M}, \mathrm{E})$ and seven nonstructural proteins (NS1, NS2A, NS2B, NS3, NS4A, NS4B and NS5) [3, 9]. The envelope glycoprotein (E), composed of three domains, is the dominant immunogen capable of eliciting a high level of neutralizing antibodies. The membrane glycoprotein (PrM) is also a potent protein candidate for genetically engineered JEV vaccines [10-16]. 
Phylogenetic analyses indicate that JEV can be divided into five genotypes (GI-GV) based on the nucleotide sequence of $E$ gene or the complete polyprotein gene [17-19]. GI-GV of JEV co-circulate in its geographically affected areas and GIII was previously dominant genotype [2]. However, GI strains have displaced GIII strains to become the predominant genotype in many Asian countries including Japan, China, Korea, Taiwan and Vietnam in recent years [20-27]. GI strains are considered to be more adapted to mosquitoes and pigs than to humans by achieving a replication cycle $[28,29]$. The currently available JE vaccines are safe and effective in preventing this disease, but they are developed based on the GIII JEV strains [30]. There are two kinds of licensed JE vaccine for swine in China, both live-attenuated virus vaccine (SA14-14-2) and inactivated virus vaccine (HW1 stain) are derived from GIII viruses. Despite the sera from 12 to 18 monthold children vaccinated with licensed Japanese encephalitis chimeric virus (JE-CV) vaccine can neutralize recently isolated viruses, the live-attenuated JEV GIII vaccine is only partial protection for GI virus in swine [31-33]. Thus, new vaccines based on JEV G1 have been required for the prevention of pigs against virus infection.

In this study, a recombinant JEV vaccine was constructed by expression of the PrM-E proteins of JEV GI using an attenuated Pseudorabies virus vector (PRV $\left.\mathrm{TK}^{-} / \mathrm{gE}^{-} / \mathrm{LacZ}^{+}\right)$. The characters of the recombinant virus $\mathrm{PRV} \mathrm{TK}^{-} / \mathrm{gE}^{-} / \mathrm{PrM}-\mathrm{E}^{+}$were evaluated and the protective immune responses to JEV were investigated in mouse model. Results showed that PRV $\mathrm{TK}^{-} / \mathrm{gE}^{-} / \mathrm{PrM}-\mathrm{E}^{+}$ not only induce humoral immunity against JEV and PRV but also confer $80 \%$ protection against $1 \times 10^{7} \mathrm{PFU}$ virulent JEV SX09S-01 strain challenge. PRV TK $/ \mathrm{gE}^{-} / \mathrm{PrM}^{+} \mathrm{E}^{+}$ is a promising candidate vaccine against JEV GI and PRV.

\section{Results}

Construction of the recombinant virus $\mathrm{PRV} \mathrm{TK}^{-} / \mathrm{gE}^{-} / \mathrm{PrM}^{-\mathrm{E}^{+}}$ The recombinant virus $\mathrm{PRV} \mathrm{TK}^{-} / \mathrm{gE}^{-} / \mathrm{PrM}-\mathrm{E}^{+}$was constructed by co-transfection with EcoRI-linearized genomic DNA of PRV TK$/ \mathrm{gE}^{-} / \mathrm{LacZ}^{+}$strain (Fig. 1a) and transfer plasmid pIE-CAG-PrM-E-BGH (Fig. 1b) with an expression cassette containing JEV PrM-E gene which regulated by the immediate early gene promoter of human cytomegalovirus. After plaque purification by three rounds of plaque assay, the total DNAs from virus-infected PK-15 cells were amplified by PCR with specific primers (Table 1) for PrM-E gene and analyzed by electrophoresis. A specific 700 bp fragment containing PrM-E gene was detected from all recombinant plaques, but was absent in the control (Fig. 2a).

To clarify the expression of PrM-E gene in the recombinant virus, PK-15 cells infected with recombinant virus PRV $\mathrm{TK}^{-} / \mathrm{gE}^{-} / \mathrm{PrM}^{-E^{+}}$or parental virus $\mathrm{PRV} \mathrm{TK}^{-} / \mathrm{gE}^{-} / \mathrm{LacZ}^{+}$ strain were collected $72 \mathrm{~h}$ after infection. Cells were lysed for western blot analysis with mAbs for $\mathrm{E}$ or for PrM as first antibody. As shown in Fig. 2, specific protein bands, with molecular masses of approximately $53 \mathrm{kDa}$ (Fig. 2b) and $19 \mathrm{kDa}$ (Fig. 2c) corresponding to the expected size of $\mathrm{E}$ and $\mathrm{PrM}$ proteins, were appeared in the PRV $\mathrm{TK}^{-} / \mathrm{gE}^{-} / \mathrm{PrM}-\mathrm{E}^{+}$virus. But no specific proteins were detected in parental virus infected cells (Fig. 2b \& c). Those results indicated that PrM and E proteins were correctly expressed in $\mathrm{PRV} \mathrm{TK}^{-} / \mathrm{gE}^{-} / \mathrm{PrM}^{-E^{+}}$infected cells.

\section{Stability and growth properties of $\mathrm{PRV}^{-} \mathrm{TK}^{-} / \mathrm{gE}^{-} / \mathrm{PrM}-\mathrm{E}^{+}$}

To further assess the genetic stability and growth kinetics of PRV $\mathrm{TK}^{-} / \mathrm{gE}^{-} / \mathrm{PrM}-\mathrm{E}^{+}$, the virus was grown on PK-15 cells sequentially for 20 passages. The viral DNA was extracted and analyzed after each passage using a pair of E-specific primers by PCR (Table 1). The expression of $\mathrm{E}$ protein was also determined by western blot analysis (Fig. 3). Results showed that the E gene was stably inserted into the PRV genome (Fig. 3a) and robustly expressed in the recombinant $\mathrm{PRV} \mathrm{TK}^{-} / \mathrm{gE}^{-} / \mathrm{PrM}^{+} \mathrm{E}^{+}$infected cells (Fig. 3b).

To compare the growth of PRV $\mathrm{TK}^{-} / \mathrm{gE}^{-} / \mathrm{PrM}-\mathrm{E}^{+}$and $\mathrm{PRV} \mathrm{TK}^{-} / \mathrm{gE}^{-} / \mathrm{LacZ}^{+}$, one-step growth curve was conducted to address whether the insertion of PrM-E gene fragment affected the replication of PRV. The $50 \%$ tissue culture infective dose $\left(\mathrm{TCID}_{50}\right)$ of recombinant virus was similar to parental virus at $0,3,6,12,18,24$, and $30 \mathrm{~h}$ post-infection (Fig. 3c). These data indicated that insertion of exogenous genes in the gE locus did not affect replication of PRV.

\section{JEV-specific immune responses in mice}

To determine whether recombinant virus $\mathrm{PRV} \mathrm{TK}^{-} /$ $\mathrm{gE}^{-} / \mathrm{PrM}^{-\mathrm{E}^{+}}$could induce JEV-specific immune responses, serum samples of $\mathrm{PRV} \mathrm{TK}^{-} / \mathrm{gE}^{-} / \mathrm{PrM}-\mathrm{E}^{+}$, $\mathrm{PRV} \mathrm{TK}^{-} / \mathrm{gE}^{-} / \mathrm{LacZ}^{+}$, DMEM and JEV inactivated vaccine vaccinated mice were collected and determined using an indirect ELISA at different weeks. JEV-specific antibodies were first detected at 2 week post-immunization (wpi) and $\mathrm{PRV} \mathrm{TK}^{-} / \mathrm{gE}^{-} / \mathrm{PrM}^{+} \mathrm{E}^{+}$ group developed significantly higher JEV-specific ELISA antibody titers than PRV $\mathrm{TK}^{-} / \mathrm{gE}^{-} / \mathrm{LacZ}^{+}$and DMEM groups $(P<0.05)$. At 6 wpi, the JEV antibodies reached a peak after booster immunization in the $\mathrm{PRV} \mathrm{TK}^{-} / \mathrm{gE}^{-} /$ PrM-E ${ }^{+}$and JEV inactivated vaccine groups (Fig. 4). The inactivated vaccine group developed significantly higher JEV-specific ELISA antibody titers than the other three groups at 2 and 6 wpi $(P<0.01)$, but there was no difference between PRV $\mathrm{TK}^{-} / \mathrm{gE}^{-} / \mathrm{PrM}-\mathrm{E}^{+}$and JEV inactivated vaccine groups at 4 and 8 wpi $(P>0.05)$.

The ability of the serum samples to neutralize JEV was evaluated using plaque reduction neutralization test 


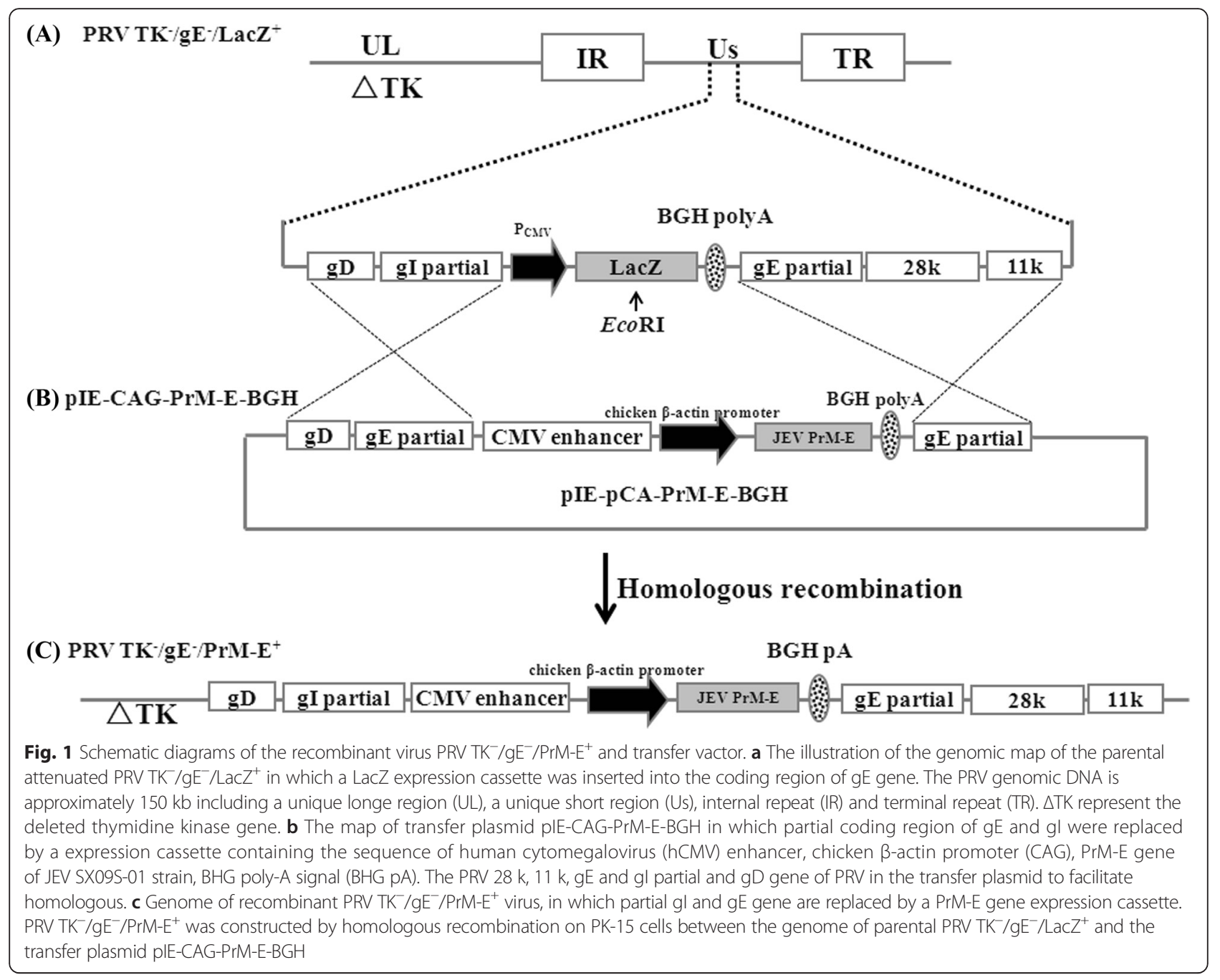

Table 1 Primers used in this study

\begin{tabular}{|c|c|}
\hline Primer & Sequence $5^{\prime} \rightarrow 3^{\prime}$ \\
\hline JEF(Forward) ${ }^{\mathrm{a}}$ & TTG GAATTC ATG ATA AGA GGA GGG AAT G \\
\hline JER(Reverse) $)^{a}$ & TाT AGATCT TTA GGC ATG CAC ATT GGT CG \\
\hline $\mathrm{JEVeF}^{\mathrm{b}}$ & GAT CTG TCG TAGCTCTTGGGTCACAG \\
\hline$J E V e R^{b}$ & GCGTTGACACCCATCCAAAGAAG \\
\hline $\mathrm{IFN}-\gamma-\mathrm{F}^{\mathrm{C}}$ & TGGCATAGATGTGGAAGAA \\
\hline IFN- $-\mathrm{R}^{\mathrm{C}}$ & GTGTGATTCAATCAATGACGCTTA \\
\hline GAPDH-F ${ }^{d}$ & GCCCAAGATGCCCTTCAGT \\
\hline GAPDH-R ${ }^{d}$ & CCTTCCGTGTTCCTACCCC \\
\hline
\end{tabular}

Primers used to the clone the PrM-E gene; ${ }^{\mathrm{b}}$ Primers used for the identification of recombinant virus $\mathrm{PRV} \mathrm{TK}^{-} / \mathrm{gE}^{-} / \mathrm{PrM}-\mathrm{E}^{+} ;{ }^{\top}$ The special primers for analysis of IFN- $\gamma$ mRNA expression through real-time RT-PCR; d: Primers used for the control of real-time RT-PCR

(PRNT) assay. Mice vaccinated with PRV TK $/ \mathrm{gE}^{-} / \mathrm{PrM}-$ $\mathrm{E}^{+}$had a little of JEV neutralizing antibody titers. Sera diluted with $1: 4$ and 1:8 have the ability to neutralize $200 \mathrm{PFU}$ JEV and reduce the plaque number. The plaque number is about $64.5 \pm 0.5$ in the control virus without serum. While the plaque number of virus mixed with different dilution of sera inoculated with $\mathrm{PRV} \mathrm{TK}^{-} / \mathrm{gE}^{-} /$ PrM- $E^{+}$is $23.5 \pm 1.5$ (1:4 dilution), $35.0 \pm 1.0$ (1:8 dilution), $55.5 \pm 0.5$ (1:16 dilution), $60.5 \pm 1.5$ (1: 32 dilution), respectively (Table 2 ). Mice vaccinated with JEV inactivated vaccine had higher neutralizing antibody titers than PRV $\mathrm{TK}^{-} / \mathrm{gE}^{-} / \mathrm{PrM}-\mathrm{E}^{+}$group. The plaque number of virus mixed with sera inoculated with JEV inactivated vaccine is $11.0 \pm 1.0$ (1:4 dilution) and $34.0 \pm 1.5$ (1: 32 dilution), respectively (Table 2). The PRV $\mathrm{TK}^{-} / \mathrm{gE}^{-} / \mathrm{LacZ}^{+}$group did not exhibit any neutralizing antibody against JEV throughout the experiment. All results showed that the neutralizing antibody titers were not high in the PRV $\mathrm{TK}^{-} / \mathrm{gE}^{-} / \mathrm{PrM}-\mathrm{E}^{+}$group. 


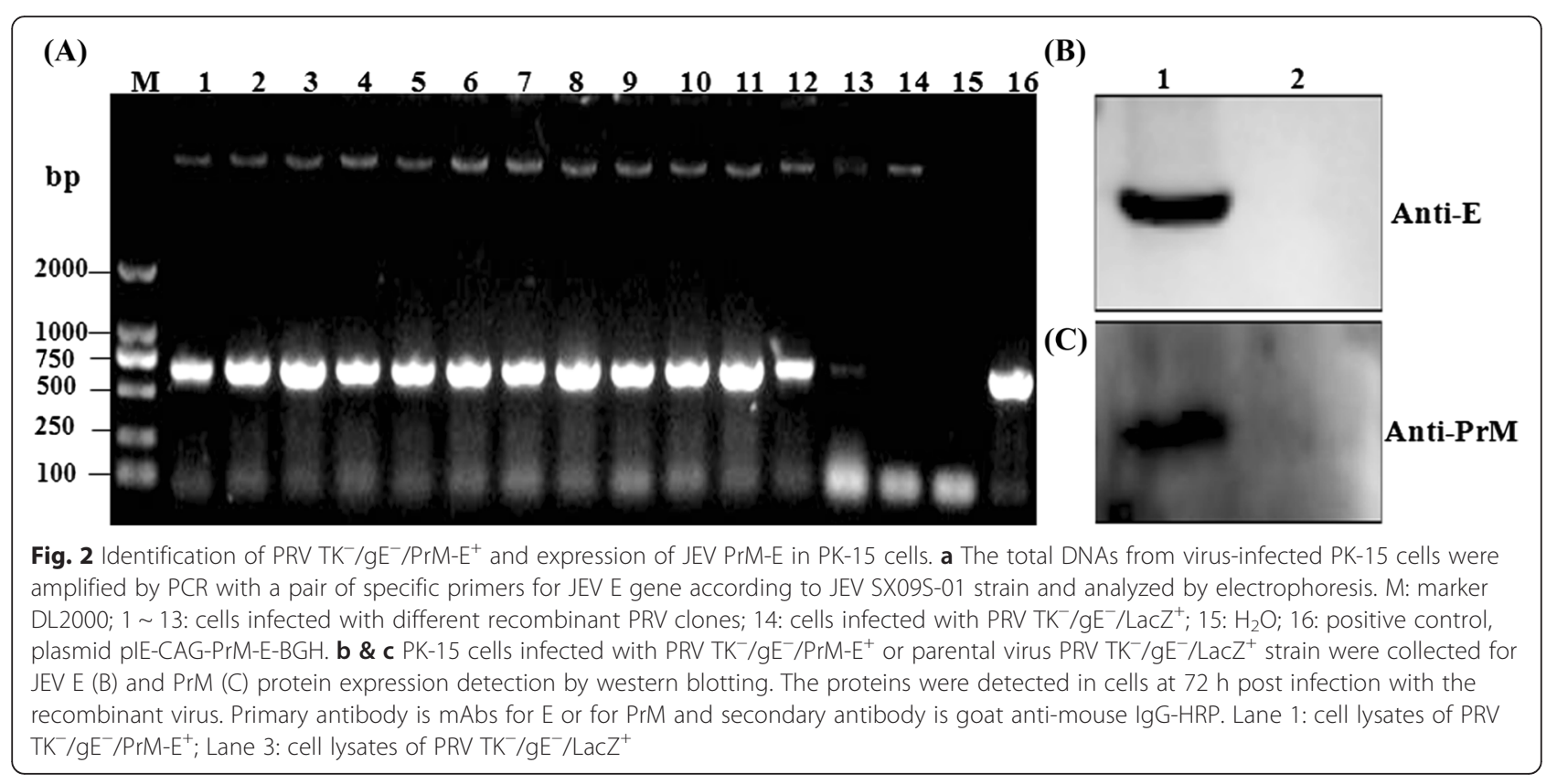

To evaluate cellular immune response to JEV, splenocytes from immunized mice were stimulated with UVinactivated JEV. The IFN- $\gamma$ mRNA expression in lymphocytes was analyzed by real-time RT-PCR. As shown in Fig. 5, PRV TK $/ \mathrm{gE}^{-} / \mathrm{PrM}^{+} \mathrm{E}^{+}$and $\mathrm{PRV} \mathrm{TK}^{-} / \mathrm{gE}^{-} / \mathrm{LacZ}^{+}$ groups elicited higher IFN- $\gamma$ mRNA expression than JEV inactivated vaccine group $(P<0.05)$. Statistical analyses indicated that there were no significant differences between $\mathrm{PRV} \mathrm{TK}^{-} / \mathrm{gE}^{-} / \mathrm{PrM}_{-} \mathrm{E}^{+}$and PRV $\mathrm{TK}^{-} / \mathrm{gE}^{-} / \mathrm{LacZ}^{+}$group $(P>0.05)$.

\section{PRV-specific humoral immune responses in mice}

To analyse whether PRV $\mathrm{TK}^{-} / \mathrm{gE}^{-} / \mathrm{PrM}^{-E^{+}}$could induce PRV-specific immune responses after immunization, we determined the specific antibodies in the vaccinated mice by indirect ELISA. As shown in Fig. 6a, all animals vaccinated with $\mathrm{PRV} \mathrm{TK}^{-} / \mathrm{gE}^{-} / \mathrm{PrM}^{+} \mathrm{E}^{+}$and $\mathrm{PRV} \mathrm{TK}^{-} / \mathrm{gE}^{-} /$ $\mathrm{LacZ}^{+}$were positive at 4 wpi. The mean titers of PRV specific antibodies significantly increased in the mice vaccinated with $\mathrm{PRV} \mathrm{TK}^{-} / \mathrm{gE}^{-} / \mathrm{PrM}^{+} \mathrm{E}^{+}$and $\mathrm{PRV} \mathrm{TK}^{-} / \mathrm{gE}^{-} /$ $\mathrm{LacZ}^{+}$and were higher than those in the mice vaccinated with DMEM and JEV inactivated vaccine $(P<0.01)$. By contrast, the PRV specific antibodies were not detected in the sera of DMEM and JEV inactivated vaccine.

Moreover, a serum neutralization test was also performed to determine the antibody against PRV. At $4 \mathrm{wpi}$, low to no neutralization antibodies against PRV was detected in PRV $\mathrm{TK}^{-} / \mathrm{gE}^{-} / \mathrm{PrM}^{+} \mathrm{E}^{+}$and $\mathrm{PRV} \mathrm{TK}^{-} / \mathrm{gE}^{-} / \mathrm{LacZ}^{+}$ groups. However, both recombinant virus and parental virus groups elicited high neutralization antibody titers at 6 wpi, there was no difference between the two groups $(P>0.05)$ (Fig. 6b). No neutralizing antibodies were detected in DMEM and JEV inactivated vaccine groups.
These results showed that PRV $\mathrm{TK}^{-} / \mathrm{gE}^{-} / \mathrm{PrM}^{+} \mathrm{E}^{+}$induced a high level of PRV ELISA and neutralizing antibodies.

\section{Vaccine Efficacy against JEV Challenge in Mice}

Animal experiments were conducted to evaluate the protective efficacy of the recombinant virus PRV $\mathrm{TK}^{-} /$ $\mathrm{gE}^{-} / \operatorname{PrM}-\mathrm{E}^{+}$against JEV challenge. Mice (ten per group) were intraperitoneally inoculated with $1 \times 10^{7}$ PFU of JEV SX09S-01 strain at 8 weeks after the primary immunization and checked daily for survival. The characteristic signs of JE such as hunched posture, ruffled fur, depressions, tremors and hind-leg paralysis were appeared at 5 day after infection (dpi) in the mice of DMEM group. 8 mice vaccinated with the recombinant virus $\mathrm{PRV} \mathrm{TK}^{-} / \mathrm{gE}^{-} / \mathrm{PrM}-\mathrm{E}^{+}$survived without showing characteristic signs of JE. Mice vaccinated with JEV inactivated vaccine showed $100 \%$ survival rates. However, survival rates of $10 \%$ were observed in mice vaccinated with $\mathrm{PRV} \mathrm{TK}^{-} / \mathrm{gE}^{-} / \mathrm{LacZ}^{+}$. These results indicated that immunization with $\mathrm{PRV} \mathrm{TK}^{-} / \mathrm{gE}^{-} / \mathrm{PrM}-\mathrm{E}^{+}$could confer $80 \%$ protective efficacy against the lethal challenge in mice.

\section{Discussion}

Japanese encephalitis (JE) is a serious arthropod-borne disease in southern and eastern Asia [1] and JEV can cause epidemic viral encephalitis in humans and reproductive disorders in swine. Currently JEV genotype I (GI) strains have displaced genotype III (GIII) strains to become the predominant genotype in some Asian countries including China and Taiwan [23, 25]. However, inactivated JEV GIII vaccine can only reduce strainspecific neutralizing antibody titers and partial 


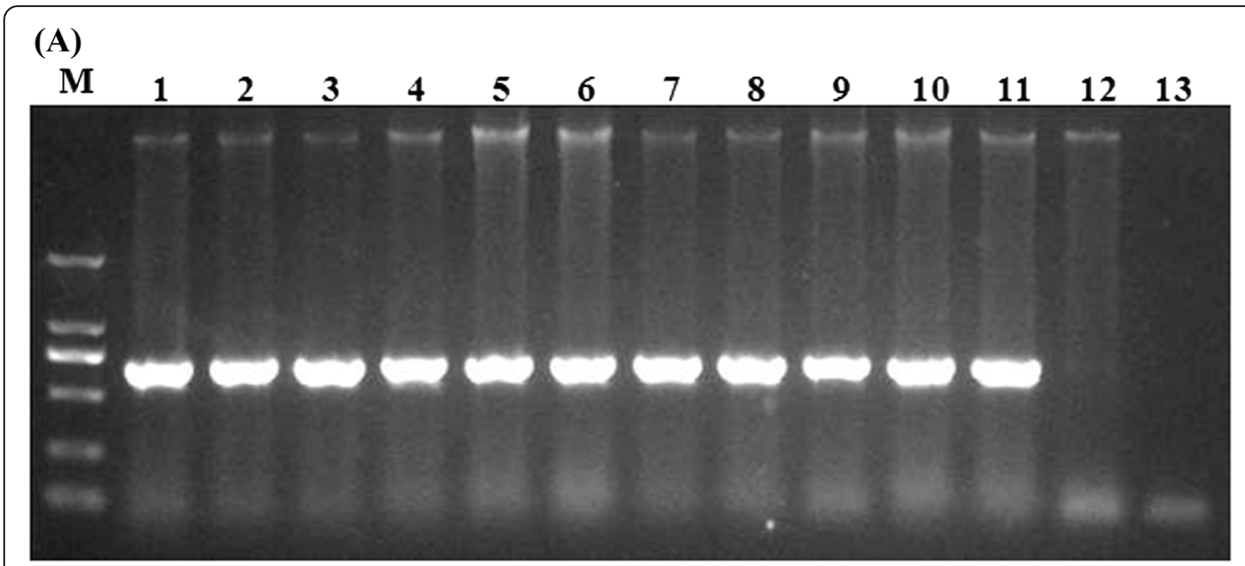

(B)

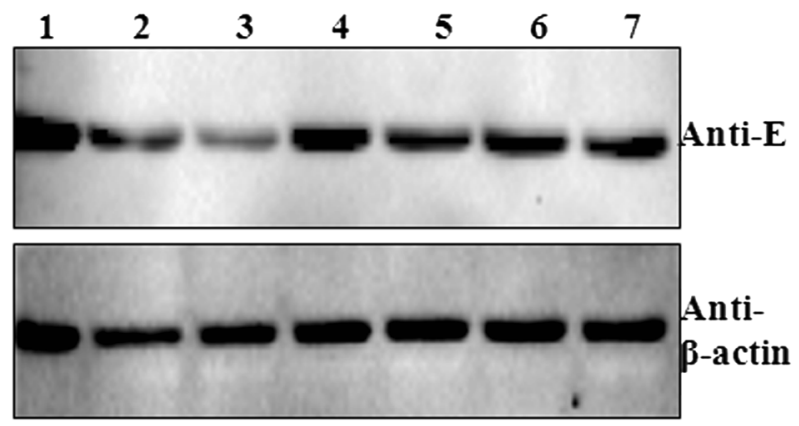

(C)

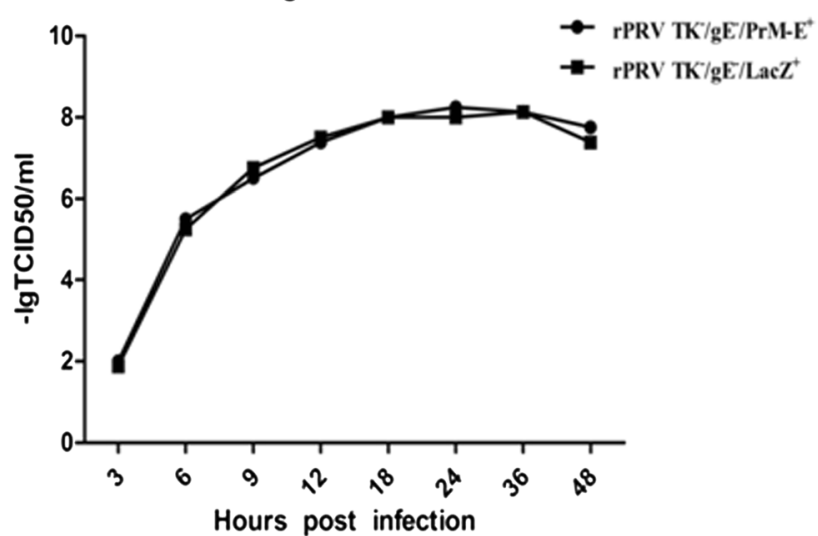

Fig. 3 The biological characteristics analysis of $\mathrm{PRV} \mathrm{TK}^{-} / \mathrm{gE}^{-} / \mathrm{PrM}^{-\mathrm{E}^{+}}$. a PRV TK $\mathrm{TK}^{-} / \mathrm{g} \mathrm{E}^{-} / \mathrm{PrM}-\mathrm{E}^{+}$was grown on PK-15 cells sequentially for 20 passages and the total DNAs from virus-infected PK-15 cells were amplified by PCR with a specific primers for JEV E gene according to JEV SX09S-01 strain and analyzed by electrophoresis. M: marker DL2000; $1 \sim 11$ : cells infected with passages 11 to 20; 12: cells infected with $\mathrm{PRV} \mathrm{TK}^{-} / \mathrm{gEE}^{-} / \mathrm{LacZ}^{+}$; 13 : $\mathrm{H} 2 \mathrm{O}$; b Genetic stability of protein identification for different generations by western blotting. PK-15 cells infected with different generations of PRV TK ${ }^{-} / \mathrm{gE}^{-} / \mathrm{PrM}-\mathrm{E}^{+}$were collected for JEV E protein expression detection by western blotting. $1 \sim 7$ : cells infected with passages 1, 2, 4, 8, 12,16 and 20 of PRV TK $/ \mathrm{gE}^{-} / \mathrm{PrM}-\mathrm{E}^{+}$. c Virus growth curves based on viral yield of supernatants harvested at different time points of PRV TK $/ \mathrm{gE}-/ \mathrm{PrM}-\mathrm{E}$ ${ }^{+}$or $\mathrm{PRV} \mathrm{TK}^{-} / \mathrm{gE}^{-} / \mathrm{LacZ}^{+}$infected PK-15 cells, and viral yield was measured by $\mathrm{TCID}_{50}$

protection against G1 virus in mice and swine [32-35]. Swine is an important amplifying and overwintering host for JEV and plays a crucial role in the human encephalitis epidemics [8]. The prevention and control of JEV infection in swine are very important to the prevention of humans. In view of the genotype shift, there is an urgent need to develop new JEV vaccines for swine to control this epidemic.

Pseudorabies virus (PRV) infection causes severe financial losses in the animal husbandry [36]. Our and other laboratories have confirmed that live attenuated pseudorabies vaccines could stimulate strong cell-mediated immune responses and high titers of neutralizing antibody against PRV and were successfully used to control PRV infection [37, 38]. Meanwhile, live attenuated PRV have been used as a highly economical promising candidate vector for the development of bivalent vaccine from animal viruses $[39,40] . \mathrm{Xu}$ et al. had determined that $\mathrm{PRV} \mathrm{TK}^{-} / \mathrm{gE}^{-} / \mathrm{NS}^{+}$expressed NS1 gene of JEV (SA1414-2) could induce JEV-specific humoral and cellular immune responses [41].

In this study, we have successfully constructed a recombinant virus PRV $\mathrm{TK}^{-} / \mathrm{gE}^{-} / \mathrm{PrM}-\mathrm{E}^{+}$expressing the premembrane (prM) and envelope (E) proteins of JEV SX09S-01 strain (GI). Precursor protein PrM-E can be accurately cleaved into PrM and E proteins by host signal peptidase (Fig. 2a and b). It has been confirmed that prM and $\mathrm{E}$ genes had been stably inserted and expressed, which did not affect the infection and replication of PRV (Fig. 3c). We further investigated the efficacy of the recombinant virus $\mathrm{PRV} \mathrm{TK}^{-} / \mathrm{gE}^{-} / \mathrm{PrM}-\mathrm{E}^{+}$ against JEV. Results indicated that both recombinant virus $\mathrm{PRV} \mathrm{TK}^{-} / \mathrm{gE}^{-} / \mathrm{PrM}-\mathrm{E}^{+}$and parental virus induced high-neutralizing and ELISA antibodies against PRV and 


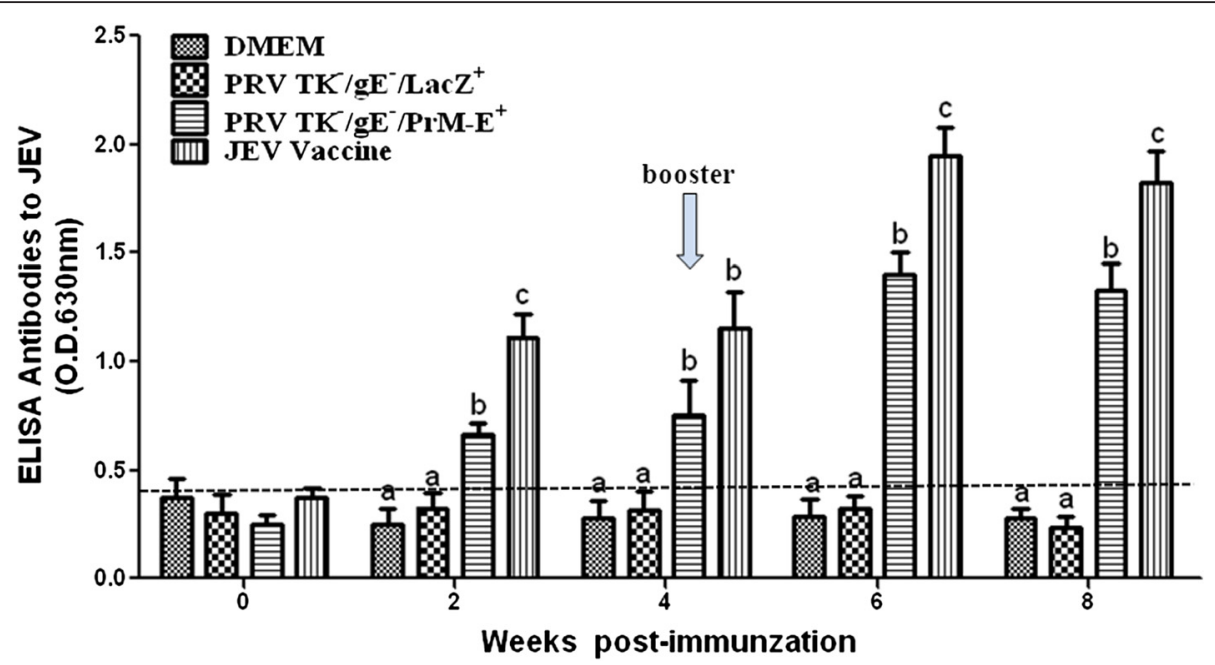

Fig. 4 Humoral immune responses of JEV in immunized mice. Serum samples were collected at weekly intervals after immunization to detect the presence of the JEV-specific antibodies by indirect ELISA. JEV-specific antibodies were found in serum samples at different times. Data represent the mean \pm SEM. Different letters indicate a statistically significant difference between the different experimental groups $(P<0.05)$. Different letters $(a, b, c)$ indicate a statistically significant difference between the different experimental groups $(P<0.05)$

there are not significant differences between them (Fig. 6). Immunization of $\mathrm{PRV} \mathrm{TK}^{-} / \mathrm{gE}^{-} / \mathrm{PrM}-\mathrm{E}^{+}$could induce humoral and cellular immune responses (Figs. 4 and 5) in the mouse model.

Specific JEV-antibodies were detected in the mice by indirect ELISA assay. These results showed that PRV $\mathrm{TK}^{-} / \mathrm{gE}^{-} / \mathrm{PrM}-\mathrm{E}^{+}$and JEV inactivated vaccine could induce high levels of the JEV-specific antibodies compared with the negative controls, $\mathrm{PRV} \mathrm{TK}^{-} / \mathrm{gE}^{-} / \mathrm{LacZ}^{+}$ and DMEM (Fig. 4). This is consistent with the previous study, which showing the recombinant $E$ protein could induce a higher titer of IgG1 indicating Th2-cells response $[42,43]$. The ability of the serum samples to neutralize JEV SX09S-01 strain was also evaluated using plaque reduction neutralization test (PRNT) assay at 8 wpi. But the neutralizing antibody titers were not high in the $\mathrm{PRV} \mathrm{TK}^{-} / \mathrm{gE}^{-} / \mathrm{PrM}^{-\mathrm{E}^{+}}$group, only the sera with $1: 4$ and 1:8 dilution showed special neutralizing effect (Table 2).

The cellular immune responses were also assessed by evaluating the mRNA expression levels of IFN- $\gamma$ which induced by the Th1 cellular response, the high level of
IFN- $\gamma$ expression were induced in mice immunized with $\mathrm{PRV} \mathrm{TK}^{-} / \mathrm{gE}^{-} / \mathrm{PrM}^{+} \mathrm{E}^{+}$and $\mathrm{PRV} \mathrm{TK}^{-} / \mathrm{gE}^{-} / \mathrm{LacZ}^{+}$. These results showed that the live-attenuated PRV could stimulate good cellular immunity (Fig. 5). Although JEV inactivated vaccine could elicit higher humoral immune responses than that of $\mathrm{PRV} \mathrm{TK}^{-} / \mathrm{gE}^{-} / \mathrm{PrM}^{-\mathrm{E}^{+}}$, the cellular immune responses are lower compared to $\mathrm{PRV} \mathrm{TK}^{-} /$ $\mathrm{gE}^{-} / \operatorname{PrM}-\mathrm{E}^{+}$. The results of JEV challenge showed that mice inoculated with inactivated JEV vaccine were completely protected and $\mathrm{PRV} \mathrm{TK}^{-} / \mathrm{gE}^{-} / \mathrm{PrM}-\mathrm{E}^{+}$conferred $80 \%$ protection (Fig. 7). In addition, DMEM control group showed typical JE signs and $\mathrm{PRV} \mathrm{TK}^{-} / \mathrm{gE}^{-} / \mathrm{LacZ}^{+}$ conferred $10 \%$ protection and it showed that cellular immunity play a crucial role against JEV challenge [44].

\section{Conclusion}

In summary, the recombinant $\mathrm{PRV} \mathrm{TK}^{-} / \mathrm{gE}^{-} / \mathrm{PrM}-\mathrm{E}^{+}$ was successfully constructed and it could efficiently express the glycoprotein PrM-E and induced humoral and cellular immunity against JEV. $80 \%$ mice were protected from challenge with JEV. Thus, PRV $\mathrm{TK}^{-} / \mathrm{gE}^{-} / \mathrm{PrM}^{+} \mathrm{E}^{+}$

Table 2 The plaque numbers of serum samples in immunized mice by plaque reduction neutralization test (PRNT) assay

\begin{tabular}{|c|c|c|c|c|}
\hline \multirow{2}{*}{$\begin{array}{l}\text { Dilution } \\
\text { of } \\
\text { Serum }^{\text {a }} \\
\end{array}$} & \multicolumn{4}{|c|}{ Numbers of Plaque by PRNT } \\
\hline & DMEM & $\mathrm{PRV} \mathrm{TK}^{-} / \mathrm{gE}^{-} / \mathrm{LacZ}^{+}$ & $\mathrm{PRV}^{\mathrm{T}} \mathrm{TK}^{-} / \mathrm{gE} \mathrm{E}^{-} / \mathrm{PrM}-\mathrm{E}^{+}$ & JEV Vaccine \\
\hline $1: 4$ & $64.5 \pm 0.5$ & $59.5 \pm 1.5$ & $23.5 \pm 1.5$ & $11.0 \pm 1.0$ \\
\hline $1: 8$ & $62.5 \pm 2.5$ & $57.5 \pm 2.5$ & $35.0 \pm 1.0$ & $19.5 \pm 0.5$ \\
\hline $1: 16$ & $63.5 \pm 1.5$ & $60.5 \pm 0.5$ & $55.5 \pm 0.5$ & $24.0 \pm 1.0$ \\
\hline $1: 32$ & $62.5 \pm 0.5$ & $63.5 \pm 1.5$ & $60.5 \pm 1.5$ & $34.0 \pm 1.5$ \\
\hline $1: 64$ & $63.0 \pm 1.5$ & $62.5 \pm 0.5$ & $63.5 \pm 0.5$ & $62.5 \pm 2.5$ \\
\hline
\end{tabular}

The sera of mice at 8 weeks post immunization was diluted and mixted with $200 \mathrm{PFU}$ of JEV SX/09/01 strain for $1 \mathrm{~h}$ at $37^{\circ} \mathrm{C}$, and then added to BHK-21 in 24 -well plate by PRNT assay 


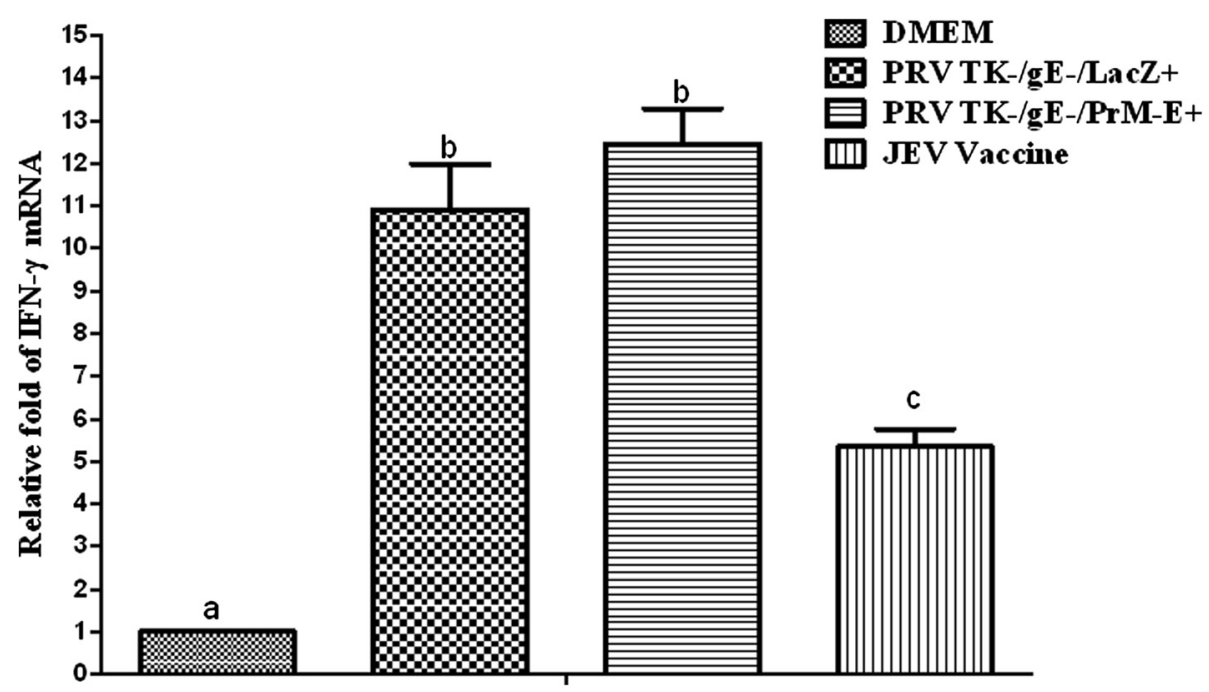

Fig. 5 Relative IFN- $\gamma$ gene expression in mice. The level of IFN- $\gamma$ per group in serum samples of mice. Data represent the mean \pm SEM. Different letters indicate a statistically significant difference between the different experimental groups $(P<0.05)$. Different letters $(a, b, c)$ indicate a statistically significant difference between the different experimental groups $(P<0.05)$

may serve as a candidate for generating a novel vaccine that can be used for controlling PRV and JEV GI strain infection. Certainly, additional studies will be conducted to evaluate the immunogenic and protective effects of these vaccines in pigs. To enhance the immune response, we are constructing recombinant viruses by co-expressing immunomodulatory molecules, such as GMCSF [45].

\section{Methods}

Viruses, cells and inactivated vaccine

The live-attenuated PRV vaccine strain ( $\mathrm{PRV} \mathrm{TK}^{-} / \mathrm{gE}^{-} /$ lac $Z^{+}$) was previously constructed and propagated on PK-15 cells used as a parental virus vector in our laboratory [46]. Japanese encephalitis virus (JEV) SX09S-01 strain, genotype GI strain, were propagated on BHK-21 cells and stored at $-80{ }^{\circ} \mathrm{C}$ to be used for animal challenge [23]. Pig kidney cells (PK-15, ATCC) and Baby hamster kidney-21 cells (BHK-21, ATCC) were grown and maintained in Dulbecco's modified Eagle's medium (DMEM, Gibco, USA) supplemented with $10 \%$ heatinactivated fetal bovine serum (FBS; Gibco, New Zealand) at $37{ }^{\circ} \mathrm{C}$ with $5 \% \mathrm{CO}_{2}$. JEV-inactivated vaccine was purchased from Jingmu Vet-biological Products Company (Wuhan, China).

\section{Plasmids construction}

All primers and the sequences used in this study were listed in Table 1. The PrM-E gene fragment was cloned from JEV SX09S-01 strain with a pair of primers JEF (Forward) and JEF (Reverse). The fragment was cloned into the EcoRI/BglII sites of the vector pCAGGS (invitrogen) under the control of the chicken $\beta$-actin promoter to generate pCA-PrM-E. A PrM-E gene expression cassette containing the enhancer of human cytomegalovirus (hCMV), chicken $\beta$-actin promoter (CAG) and PrM-E gene from pCA-PrM-E was further subcloned into the SalI-BglII sites of universal transfer vector pIECMV-BGH-CMV-SV40 (constructed previously in our laboratory) and the resulting transfer plasmid was named as pIE-CAG-PrM-E-BGH (Fig. 1b).

Construction of recombinant viruses $\mathrm{PRV} \mathrm{TK}^{-} / \mathrm{gE}^{-} / \mathrm{PrM}-\mathrm{E}^{+}$ The recombinant virus $\mathrm{PRV} \mathrm{TK}^{-} / \mathrm{gE}^{-} / \mathrm{PrM}^{+} \mathrm{E}^{+}$was constructed by homologous recombination between the genome of PRV TK $/ \mathrm{gE}^{-} / \mathrm{LacZ}^{+}$digested with EcoRI and plasmid pIE-CAG-PrM-E-BGH (Fig. 1) according to the method described by Qian P [39]. Co-transfection was conducted in PK-15 cells using Lipofectamine 2000 (Invitrogen) with the method of manufacturer's instruction. After cytopathogenic effect (CPE) appeared, the transfected cells were collected $48 \sim 72 \mathrm{~h}$ later. The recombinant virus $\mathrm{PRV} \mathrm{TK}^{-} / \mathrm{gE}^{-} / \mathrm{PrM}-\mathrm{E}^{+}$was subjected to plaque purification and identification with PCR for amplifying a small fragment of PrM-E gene with a pair of primers JEVeF and JEVeR (Table 1). Expression of JEV $\operatorname{PrM}$ and $\mathrm{E}$ proteins was analyzed by Western blot analysis.

\section{Detection the expression of PrM and $E$ protein}

PrM and E protein expression was evaluated by Western blot analysis using monoclonal antibodies (MAbs). The $\mathrm{mAbs}$ against $\mathrm{E}$ and PrM were kindly provided by professor Cao shengbo and Doctor Song yunfeng (Huazhong Agriculture University) [47]. The lysates from PRV $\mathrm{TK}^{-} / \mathrm{gE}^{-} / \mathrm{PrM}-\mathrm{E}^{+}$infected cells were separated by SDS- 


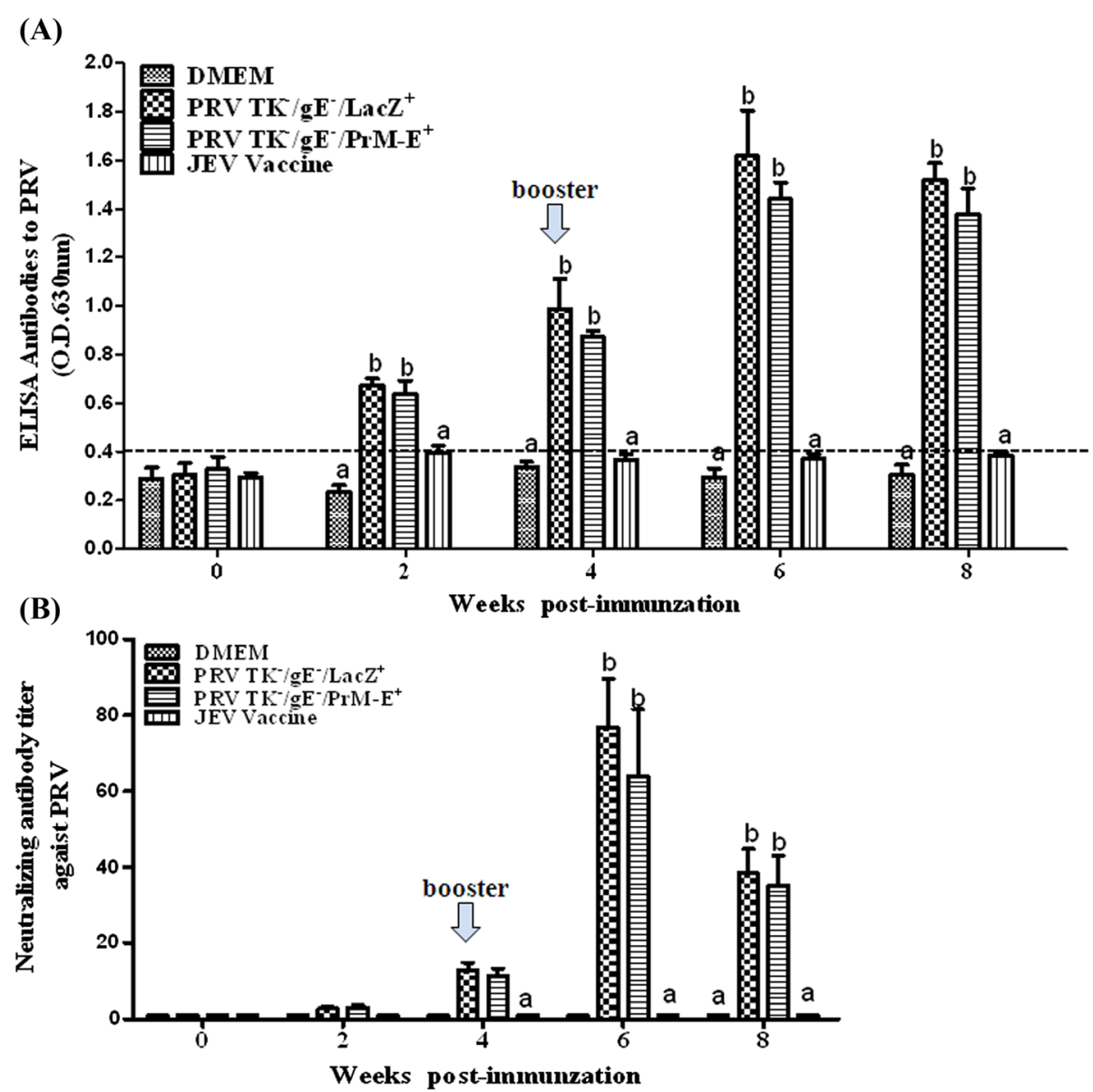

Fig. 6 Humoral immune responses against PRV in immunized mice. Serum samples were collected at weekly intervals after immunization. a Serum samples of PRV-specific antibodies using the PRV-gB Antibody Test Kit by indirect ELISA, according to the manufacturer's instructions. b PRV Neutralizing antibodies were measured in serum samples at different times by serum neutralization test. PRV Neutralizing antibodies were calculated and expressed as the reciprocal of the highest serum dilution that inhibits $50 \%$ of the culture wells of the PRV replication. Data represent the mean \pm SEM. Statistical significance was assessed by Student's $t$-test $(* * *: P<0.001)$. Data represent the mean \pm SEM. Different letters $(a, b, c)$ indicate a statistically significant difference between the different experimental groups $(P<0.05)$

PAGE gel and transferred to polyvinylidene difluoride membranes (Roche). The nonspecific antibody-binding sites were blocked by $5 \%$ skim milk in Tris Buffered Saline (TBS). The E and PrM MAbs and horseradish peroxides (HRP)-conjugated goat anti-mouse IgG (1:2000 dilution, ABclonal, Wuhan, Hubei, China) were used as the primary and the secondary antibody. The bands were visualized using Electro-Chemi-Luminescence kit (Thermo, USA) according to the manufacturer's instructions.

\section{Stability and Growth properties of $\mathrm{PRV}^{-} \mathrm{TK}^{-} / \mathrm{gE}^{-} / \mathrm{PrM}-\mathrm{E}^{+}$}

To analyze the genetic stability of the foreign gene in the recombinant virus $\mathrm{PRV} \mathrm{TK}^{-} / \mathrm{gE}^{-} / \mathrm{PrM}-\mathrm{E}^{+}$, the virus was sequentially grown on PK-15 cells and viral DNA was extracted and analyzed after each passage using Especific primers by PCR. At the same time, the expression of JEV E protein after each passage was determined by Western blot analysis. One step growth kinetic assay was performed to determine the titer of recombinant virus $\mathrm{PRV} \mathrm{TK}^{-} / \mathrm{gE}^{-} / \mathrm{PrM}-\mathrm{E}^{+}$as previously described [48]. Briefly, cells were infected at a multiplicity of infection (MOI) of 0.02 and harvested at different time points. The virus was titrated by $50 \%$ tissue culture infective dose $\left(\mathrm{TCID}_{50}\right)$ assay in PK-15 cells.

\section{Immunization and viral challenge of mice}

Four-week old female SPF Balb/c mice were purchased from Zhongnan Hospital of Wuhan University (Hubei Province, China) and randomly divided into four groups (10 mice per group). Groups A and B were inoculated intramuscularly (i.m.) with $100 \mu \mathrm{l}\left(1.0 \times 10^{6} \mathrm{TCID}_{50}\right)$ of

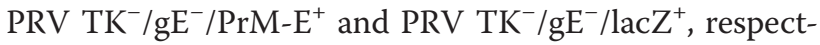
ively. Group C and D were inoculated i.m. with $100 \mu \mathrm{l}$ of DMEM and $100 \mu \mathrm{l} \mathrm{JEV} \mathrm{inactivated} \mathrm{vaccine} \mathrm{(SA14-14-2,}$ immunization dose reference to instructions) as 
Fig. 7 Survival rate of immunized mice after lethal JEV challenge. Four-week-old female BALB/C mice were challenged with $1 \times 10^{7} \mathrm{PFU}$ of virulent JEV SX09S-01 strain as described in Materials and methods. At day 10 after challenge, no mice survived in the DMEM group (0 \%) and 8 mice survived in the PRV TK-/gE-/PrM-E+ group ( $80 \%$ ). JEV inactivated vaccine induced perfect protection rate $100 \%$. There was one mouse survived in the PRV TK-/gE-/LacZ+ group (10\%). The survival rate at 10 days was determined as 100x (number of survivors)/(number of challenged mice).

controls. Booster injection was administered with the same dose at 4 weeks post-immunization (wpi). At 8 weeks after the primary immunization, mice were intraperitoneally inoculated with $100 \mu \mathrm{l}\left(1 \times 10^{7} \mathrm{PFU}\right)$ of JEV SX09S-01 strain and checked for survival [49]. After JEV challenge, the signs of JE and survival rates were monitored daily for 10 days as previously described [44].

\section{Antibody detection using ELISA assays}

Serum samples were collected at 0, 2, 4, 6 and 8 weeks after the initial immunization and were tested using an indirect ELISA with PRV or JEV antibody ELISA kit (Wuhan KeQian Biological Co., Ltd.), which was placed on microplates coated with gB protein of PRV or inactivated JEV virus antigen, according to the manufacturer's instructions. The sera were dealed with 1:40 dilution and the samples were considered positive when $\mathrm{OD}_{630}>0.40$ while negative when $\mathrm{OD}_{630}<0.40$ for PRV, and positive when $\mathrm{OD}_{630}>0.45$ while negative when $\mathrm{OD}_{630}<0.45$ for JEV.

\section{Serum neutralization test}

PRV neutralizing antibodies were measured in serum samples at different times. The serum neutralization test was performed as previously described [39]. $50 \mu \mathrm{l}$ of serum samples were two-fold serially diluted and mixed with equal volume of viral suspension containing 100 $\mathrm{TCID}_{50}$ PRV Ea strain for $1 \mathrm{~h}$ at $37{ }^{\circ} \mathrm{C}$ in 96-well flatbottomed tissue culture plates (Nunc, USA). The mixture was then inoculated for $1 \mathrm{~h}$ at $37{ }^{\circ} \mathrm{C}$ and $5 \%$ $\mathrm{CO}_{2} .100 \mu \mathrm{l}$ of PK-15 cells suspension $\left(\mathrm{ca} .1 .0 \times 10^{6} \mathrm{ml}^{-1}\right.$ ) was added to each well and inoculated for another 4-5 days. The plates were observed under a microscope for cytopathic effect.

The JEV neutralizing antibodies were also detected with plaque reduction neutralization test (PRNT) by using monolayers of BHK-21 cells according to the method of Yang DK [43]. Briefly, $3 \times 10^{4}$ BHK-21 cells were seeded into 24-well plates and incubated until a monolayer formed at $37{ }^{\circ} \mathrm{C}$. The heat inactivated sera were two-fold serially diluted and mixed with an equal volume of 200 PFU of JEV SX09S-01 strain. The mixture were incubated for $1 \mathrm{~h}$ at $37^{\circ} \mathrm{C}$ and then added to BHK21 cells monolayer in 24-well plate. Then the virus solution was aspirated, cells in each well were washed three times with phosphate-buffered saline (PBS, $\mathrm{pH}$ 7.4) and overlaid with $1.0 \mathrm{ml}$ of $4 \%$ carboxymethylcellulose (CMC) in growth medium (DMEM without phenol red, supplemented with $3 \% \mathrm{FCS}$ ) and incubated at $37{ }^{\circ} \mathrm{C}$ and $5 \% \mathrm{CO}_{2}$ for 5 days. After virus plaques were formed, cells were fixed with $10 \%$ formalin and stained with $1 \%$ crystal violet. The $\mathrm{PRNT}_{50}$ titers were calculated as the reciprocal of the dilution of serum that reduced the plaque number by at least $50 \%$ of that in the virus control.

\section{Analysis of IFN- $\gamma$ mRNA expression through real-time RT- PCR}

Splenocytes from mice immunized were isolated from spleen and were cultured in 12-well plates for $20 \mathrm{~h}$ with $20 \mu \mathrm{L}$ of UV-inactivated JEV (SX09S-01 strain, MOI = 1). Total RNA was extracted and the cDNA product was further amplified with $\mathrm{SYBR}^{\bullet}$ Green Real-time PCR Master Mix (ToYoBo) and specific primers (Table 1). Each experiment was performed in triplicate. PCR amplification was performed under the following conditions: $2 \mathrm{~min}$ at $50{ }^{\circ} \mathrm{C}, 10 \mathrm{~min}$ at $94{ }^{\circ} \mathrm{C}$, and 40 cycles of $15 \mathrm{~s}$ at $94{ }^{\circ} \mathrm{C}$ and $1 \mathrm{~min}$ at $5{ }^{\circ} \mathrm{C}$. Gene expression was determined using the relative quantity and then analyzed as previously described [44].

\section{Statistical analysis}

Statistical analysis was conducted using the GraphPad Prism Version 5 (GraphPad Software, La Jolla, CA, USA, 2012). One-way ANOVA was used for statistical analyses among different groups. $P$-value less than 0.05 was considered statistically significant.

\section{Competing interests}

The authors declare that they have no competing interests.

\section{Authors' contributions}

Designed the experiments: $\mathrm{PQ}, \mathrm{XML}$, and HCC; Performed the experiments: BW; analyzed the data: HWZ, XML and PQ; Wrote the paper: XML, XWZ; Proofed the manuscript: XML, PQ, XWZ and HCC. All authors read and approved the final manuscript.

\section{Acknowledgments}

This work was supported by the National Programs for High Technology Research and Development of China (No. 2011AA10A212), Research and Technological Development project of Guangxi Province (14125008-2-18) and Fundamental Research Funds for the Central Universities (2010PY001, 2011PY050)

\section{Author details}

${ }^{1}$ State Key Laboratory of Agricultural Microbiology, Huazhong Agricultural University, Wuhan, Hubei, P.R. China. 'Laboratory of Animal Virology, College of Veterinary Medicine, Huazhong Agricultural University, Wuhan, Hubei, P.R. China. ${ }^{3}$ Key Laboratory of development of veterinary diagnostic products, Ministry of Agriculture, Wuhan 430070, P.R China. 


\section{Received: 26 August 2015 Accepted: 4 December 2015} Published online: 10 December 2015

\section{References}

1. Centers for Disease Control and Prevention (CDC). Japanese encephalitis surveillance and immunization-Asia and the Western Pacific, 2012. MWR Morb Mortal Wkly Rep. 2013;62:658-62.

2. Lindenbach BD, Murray CL, Thiel HJ, Rice CM. Flaviviridae. In: Knipe DM, Howley PM, editors. Fields Virology, 6ed. Philadelphia, PA: Lippincott Williams \& Wilkins; 2013. p712-746.

3. Pierson TC, Diamond MS. Flaviviruses. In: Knipe DM, Howley PM, editors. Fields Virology, 6ed. Philadelphia, PA: Lippincott Williams \& Wilkins; 2013. p747-795.

4. Solomon T. Control of Japanese encephalitis — within our grasp? N Engl J Med. 2006:355:869-71.

5. Campbell GL, Hills SL, Fischer M, Jacobson JA, Hoke CH, Hombach JM, et al. Estimated global incidence of Japanese encephalitis: a systematic review. Bull World Health Organ. 2011;89:766-74. 774A-774E.

6. Sarkari NB, Thacker AK, Barthwal SP, Mishra VK, Prapann S, Srivastava D, et al. Japanese encephalitis (JE) part II: 14 years' follow-up of survivors. J Neurol. 2012;259:58-69

7. Misra UK, Kalita J, Goel D, Mathur A. Clinical, radiological and neurophysiological spectrum of JEV encephalitis and other non-specific encephalitis during post-monsoon period in India. Neurol India. 2003;51:55-9.

8. Weaver SC, Barrett AD. Transmission cycles, host range, evolution and emergence of arboviral disease. Nat Rev Microbiol. 2004;2:789-801.

9. Unni SK, Ruzek D, Chhatbar C, Mishra R, Johri MK, Singh SK. Japanese encephalitis virus: from genome to infectome. Microbes Infect. 2011;13:312-21.

10. Rey FA, Heinz FX, Mandl C, Kunz C, Harrison SC. The envelope glycoprotein from tick-borne encephalitis virus at 2 A resolution. Nature. 1995;375:291-8.

11. Chen HW, Pan CH, Liau MY, Jou R, Tsai CJ, Wu HJ, et al. Screening of protective antigens of Japanese encephalitis virus by DNA immunization: a comparative study with conventional viral vaccines. J Virol. 1999;73:10137-45.

12. Li J, Chen H, Wu N, Fan D, Liang G, Gao N, et al. Characterization of immune responses induced by inactivated, live attenuated and DNA vaccines against Japanese encephalitis virus in mice. Vaccine. 2013;31:4136-42.

13. Kanesa-thasan N, Smucny JJ, Hoke CH, Marks DH, Konishi E, Kurane I, et al. Safety and immunogenicity of NYAC-JEV and ALVAC-JEV attenuated recombinant Japanese encephalitis virus-poxvirus vaccines in vaccinianonimmune and vaccinia-immune humans. Vaccine. 2000;19:483-91.

14. Li P, Zheng QS, Wang Q, Li Y, Wang EX, Liu JJ, et al. Immune responses of recombinant adenoviruses expressing immunodominant epitopes against Japanese encephalitis virus. Vaccine. 2008:26:5802-7.

15. Konishi E, Yamaoka M, Kurane I, Mason PW. Japanese encephalitis DNA vaccine candidates expressing premembrane and envelope genes induce virus-specific memory B cells and long-lasting antibodies in swine. Virology. 2000;268:49-55.

16. Chambers TJ, Nestorowicz A, Mason PW, Rice CM. Yellow fever/Japanese encephalitis chimeric viruses: construction and biological properties. J Virol. 1999:73(4):3095-101.

17. Williams DT, Wang LF, Daniels PW, Mackenzie JS. Molecular characterization of the first Australian isolate of Japanese encephalitis virus, the FU strain. J Gen Virol. 2000:81:2471-80.

18. Solomon T, Ni H, Beasley DW, Ekkelenkamp M, Cardosa MJ, Barrett AD. Origin and evolution of Japanese encephalitis virus in southeast Asia. J Virol. 2003;77:3091-8

19. Li MH, Fu SH, Chen WX, Wang HY, Guo YH, Liu QY, et al. Genotype v Japanese encephalitis virus is emerging. PLoS Negl Trop Dis. 2011;5:e1231.

20. Ma SP, Yoshida Y, Makino Y, Tadano M, Ono T, Ogawa M. Short report: a major genotype of Japanese encephalitis virus currently circulating in Japan. Am J Trop Med Hyg. 2003;69:151-4.

21. Wang HY, Takasaki T, Fu SH, Sun XH, Zhang HL, Wang ZX, et al. Molecular epidemiological analysis of Japanese encephalitis virus in China. J Gen Virol. 2007;88:885-94.

22. Yun SM, Cho JE, Ju YR, Kim SY, Ryou J, Han MG, et al. Molecular epidemiology of Japanese encephalitis virus circulating in South Korea, 1983-2005. Virol J. 2010:7:127.

23. Cao QS, Li XM, Zhu QY, Wang DD, Chen HC, Qian P. Isolation and molecular characterization of genotype 1 Japanese encephalitis virus, SX09S-01, from pigs in China. Virol J. 2011;8:472.
24. Pan XL, Liu H, Wang HY, Fu SH, Liu HZ, Zhang HL, et al. Emergence of genotype I of Japanese encephalitis virus as the dominant genotype in Asia. J Virol. 2011;85:9847-53.

25. Su CL, Yang CF, Teng HJ, Lu LC, Lin C, Tsai KH, et al. Molecular epidemiology of Japanese encephalitis virus in mosquitoes in Taiwan during 2005-2012. PLoS Negl Trop Dis. 2014:8:e3122.

26. Schuh AJ, Ward MJ, Leigh Brown AJ, Barrett AD. Dynamics of the emergence and establishment of a newly dominant genotype of Japanese encephalitis virus throughout Asia. J Virol. 2014;88:4522-32.

27. Do LP, Bui TM, Hasebe F, Morita K, Phan NT. Molecular epidemiology of Japanese encephalitis in northern Vietnam, 1964-2011: genotype replacement. Virol J. 2015;12:51.

28. Nga PT, del Carmen PM, Cuong VD, Ma SP, Hasebe F, Inoue S, et al. Shift in Japanese encephalitis virus (JEV) genotype circulating in northern Vietnam: implications for frequent introductions of JEV from Southeast Asia to East Asia. J Gen Virol. 2004;85:1625-31

29. Han N, Adams J, Chen P, Guo ZY, Zhong XF, Fang W, et al. Comparison of Genotypes I and III in Japanese Encephalitis Virus Reveals. Distinct Differences in Their Genetic and Host Diversity. J Virol. 2014;88:11469-79.

30. Halstead SB, Thomas SJ. New Japanese encephalitis vaccines: alternatives to production in mouse brain. Expert Rev Vaccines. 2011:10:355-64.

31. Bonaparte M, Dweik B, Feroldi E, Meric C, Bouckenooghe A, Hildreth S, et al. Immune response to live-attenuated Japanese encephalitis vaccine (JE-CV) neutralizes Japanese encephalitis virus isolates from south-east Asia and India. BMC Infect Dis. 2014;14:156.

32. Fan YC, Chen JM, Chiu HC, Chen YY, Lin JW, Shih CC, et al. Partially neutralizing potency against emerging genotype I virus among children received formalin-inactivated Japanese encephalitis virus vaccine. PLoS Negl Trop Dis. 2012;6:e1834

33. Fan YC, Chen JM, Chen YY, Lin JW, Chiou SS. Reduced neutralizing antibody titer against genotype I virus in swine immunized with a live-attenuated genotype III Japanese encephalitis virus vaccine. Vet Microbiol. 2013;163:248-56.

34. Liu X, Yu Y, Li M, Liang G, Wang H, Jia L, et al. Study on the protective efficacy of SA14-14-2 attenuated Japanese encephalitis against different JE virus isolatescirculating in China. Vaccine. 2011; 29:2127-30.

35. Beasley DW, Li L, Suderman MT, Guirakhoo F, Trent DW, Monath TP, et al. Protection against Japanese encephalitis virus strains representing four genotypes by passive transfer of sera raised against ChimeriVax-JE experimental vaccine. Vaccine. 2004;22:3722-6.

36. Zuckermann FA. Aujeszky's disease virus: opportunities and challenges. Vet Res. 2000;31:121-31.

37. van Zijl M, Wensvoort $\mathrm{G}$, de Kluyver E, Hulst M, van der Gulden H, Gielkens A, et al. Live attenuated pseudorabies virus expressing envelope glycoprotein E1 of hog cholera virus protects swine against both pseudorabies and hog cholera. J Virol. 1991;65:2761-5.

38. van Iddekinge BJL $H$, de Wind N, Wensvoort $G$, Kimman TG, Gielkens ALJ, Moormann RJM. Comparison of the protective efficacy of recombinant pseudorabies viruses against pseudorabies and classical swine fever in pigs; influence of different promoters on gene expression and on protection. Vaccine. 1996;14:6-12.

39. Qian $\mathrm{P}$, Li XM, Jin ML, Peng GQ, Chen HC. An approach to a FMD vaccine based on genetic engineered attenuated pseudorabies virus: one experiment using VP1 gene alone generates an antibody responds on FMD and pseudorabies in swine. Vaccine. 2004;22:2129-36.

40. Dong B, Zarlenga DS, Ren X. An overview of live attenuated recombinant pseudorabies viruses for use as novel vaccines. J Immunol Res. 2014;2014: 824630

41. Xu G, Xu X, Li Z, He Q, Wu B, Sun S, et al. Construction of recombinant pseudorabies virus expressing NS1 protein of Japanese encephalitis (SA1414-2) virus and its safety and immunogenicity. Vaccine. 2004;22:1846-53.

42. Lobigs M, Pavy M, Hall RA, Lobigs P, Cooper P, Komiya T, et al. An inactivated Vero cell-grown Japanese encephalitis vaccine formulated with Advax, a novel inulin-based adjuvant, induces protective neutralizing antibody against homologous and heterologous flaviviruses. J Gen Virol. 2010;91:1407-17.

43. Yang DK, Kweon CH, Kim BH, Lim SI, Kwon JH, Kim SH, et al. Immunogenicity of baculovirus expressed recombinant proteins of Japanese encephalitis virus in mice. J Vet Sci. 2005;6:125-33.

44. Li Y, Ye J, Cao S, Xiao S, Zhao Q, Liu X, et al. Immunization with pseudotype baculovirus expressing envelope protein of Japanese encephalitis virus elicits protective immunity in mice. J Gene Med. 2009;11:57-65. 
45. Yang DK, Nah JJ, Kim HH, Song JY. Inactivated genotype 1 Japanese encephalitis vaccine for swine. Clin Exp Vaccine Res. 2014;3:212-9.

46. Liu Z, Chen H, He Q, Zhou F, Fang L. Construction of pseudorabies virus Ea TK-/gE-/gp63-mutant strain and the study on its biological property. Wei Sheng Wu Xue Bao. 2002:42:370-4.

47. Li Y, Hou L, Ye J, Liu X, Dan H, Jin M, et al. Development of a convenient immunochromatographic strip for the diagnosis of infection with Japanese encephalitis virus in swine. J Virol Methods. 2010;168:51-6.

48. Yao L, Wu CX, Zheng $\mathrm{K}, \mathrm{Xu} X \mathrm{XJ}$, Zhang $\mathrm{H}$, Chen CF, et al. Immunogenic response to a recombinant pseudorabies virus carrying bp26 gene of Brucella melitensis in mice. Res Vet Sci. 2015;100:61-7.

49. Lin $\mathrm{YL}$, Liao $\mathrm{CL}$, Yeh $\mathrm{CT}$, Chang $\mathrm{CH}$, Huang $\mathrm{YL}$, Huang $\mathrm{YY}$, et al. A highly attenuated strain of Japanese encephalitis virus induces a protective immune response in mice. Virus Res. 1996;44:45-56.

\section{Submit your next manuscript to BioMed Central} and we will help you at every step:

- We accept pre-submission inquiries

- Our selector tool helps you to find the most relevant journal

- We provide round the clock customer support

- Convenient online submission

- Thorough peer review

- Inclusion in PubMed and all major indexing services

- Maximum visibility for your research

Submit your manuscript at www.biomedcentral.com/submit 